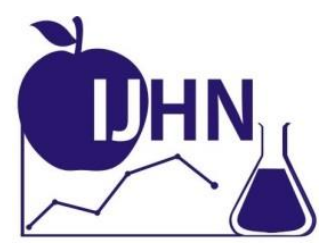

\title{
Potensi Ekstrak Etanol Ubi Jalar Ungu sebagai Inhibitor Angiotensin Converting Enzyme pada Tikus Hipertensi
}

\author{
Irma Sarita Rahmawati ${ }^{1}$, Soetjipto ${ }^{2}$, Annis Catur Adi ${ }^{3}$, Aulanni'am ${ }^{4}$, Annisa \\ Rizky Maulidiana ${ }^{1}$ \\ ${ }^{1}$ Jurusan Gizi, Fakultas Kedokteran, Universitas Brawijaya, Indonesia \\ ${ }^{2}$ Departemen Biokimia, Fakultas Kedokteran, Universitas Airlangga, Indonesia \\ ${ }^{3}$ Jurusan Gizi, Fakultas Kesehatan Masyarakat, Universitas Airlangga, Indonesia \\ ${ }^{4}$ Fakultas Kedokteran Hewan, Universitas Brawijaya, Indonesia \\ * Alamat korespondensi: irma_sr@ub.ac.id
}

Direview: Juni 2021

Dimuat: Juli 2021

\begin{abstract}
Abstrak
Hipertensi disebabkan oleh adanya aktivasi sistem renin-angiotensin-aldosteron (RAA) dan stres oksidatif yang dapat merusak berbagai struktur fungsi organ tubuh seperti sistem kardiovaskular dan ginjal. Ubi jalar ungu mengandung senyawa bioaktif berupa asam klorogenat dan antosianin sebagai antihipertensi dan anti-angiotensin converting enzyme (ACE) dalam sistem RAA. Penelitian ini bertujuan untuk menganalisis efek ekstrak etanol ubi jalar ungu (EU) var. Ayamurasaki pada aktivitas anti-ACE dalam sistem RAA tikus hipertensi yang diinduksi oleh deoxycorticosterone acetate-salt (DOCA-salt). Jenis penelitian ini adalah eksperimental laboratorik dengan menggunakan 30 ekor tikus putih (Rattus norvegicus) strain Wistar sebagai hewan coba. Tikus diberi ekstrak EU per oral dengan dosis harian 200 dan $400 \mathrm{mg} / \mathrm{kgBB}$ serta asam klorogenat (AK) $0,4 \mathrm{mg} / \mathrm{kgBB}$ selama 4 minggu. Pengukuran aktivitas enzim renin, ACE, dan kadar Angiotensin II menggunakan ELISA kit dengan sampel serum darah tikus. Analisis statistik ANOVA menunjukkan bahwa pemberian dosis EU $400 \mathrm{mg} / \mathrm{kgBB}$ dan AK 0,4 mg/kgBB mampu menurunkan aktivitas enzim renin dan ACE serta kadar angiotensin II secara bermakna pada tikus hipertensi induksi DOCA-salt dibandingkan dengan kelompok kontrol positif $(\mathrm{p}<0,05)$. Dapat disimpulkan bahwa ekstrak etanol dan asam klorogenat ubi jalar ungu (EU) varian Ayamurasaki mampu menghambat ACE pada tikus model hipertensi dengan induksi DOCA-salt.
\end{abstract}

Kata kunci: ubi jalar ungu, DOCA-salt, asam klorogenat, antihipertensi, ACE-Inhibitor

\section{Abstract}

Hypertension is caused by the activation of the renin-angiotensin-aldosterone system (RAAS) and oxidative stress that could damage various structures and functions of organs, such as the cardiovascular system and kidneys. Purple sweet potato contains bioactive compounds in the form of chlorogenic acid and anthocyanins as an antihypertensive and anti-angiotensin converting enzyme (ACE) in the RAAS. This study aimed to analyze the effect of ethanol extract of purple sweet 
potato (EU) var. Ayamurasaki on anti-ACE activity in the RAAS of hypertensive rats induced by deoxycorticosterone acetate-salt (DOCA-salt). This research was an experimental laboratory using 30 white rats (Rattus norvegicus) Wistar strain as experimental animals. Rats were given EU extract orally with daily doses of 200 and $400 \mathrm{mg} / \mathrm{kgBW}$ and $0.4 \mathrm{mg} / \mathrm{kgBW}$ chlorogenic acid (AK) for four weeks. Measurements of renin and ACE activities as well as Angiotensin II levels of the rat blood serum samples were using ELISA kit. The ANOVA statistical analysis showed that the EU $400 \mathrm{mg} / \mathrm{kgBW}$ and $A K 0.4 \mathrm{mg} / \mathrm{kgBW}$ doses were able to significantly reduce renin and $A C E$ activities as well as angiotensin II levels in DOCA-salt-induced hypertensive rats compared to the positive control group $(p<0.05)$. It can be concluded that the ethanol extract and chlorogenic acid of purple sweet potato (EU) var. Ayamurasaki was able to inhibit ACE in hypertensive rat model by DOCA-salt induction.

Keywords: ACE-Inhibitor, antihypertension, chlorogenic acid, DOCA-salt, purple sweet potato

\section{PENDAHULUAN}

Hipertensi merupakan penyebab utama kematian yang berhubungan dengan penyakit kardiovaskular, penyakit serebrovaskular, dan penyakit ginjal. Hipertensi memiliki prevalensi $26,4 \%$ pada populasi orang dewasa, dengan total hampir satu miliar individu, dan diperkirakan akan meningkat hingga 29\% (1,5 miliar) pada tahun 2025 [1]. Aktivasi sistem renin-angiotensin-aldosteron (RAAS) yang merupakan kaskade hormonal memiliki peran penting dalam patogenesis hipertensi. Angiotensin-II, vasokonstriktor kuat, adalah produk aktif utama dari RAAS yang memainkan peran sentral dalam perkembangan hipertensi [2].

Hipertensi juga dikaitkan dengan stres oksidatif yang dihasilkan dari ketidakseimbangan antara produksi spesies oksigen reaktif (ROS) dan sistem pertahanan antioksidan. Dalam hal ini, produksi ROS oleh NADPH oksidase yang meningkat dapat menyebabkan percepatan penuaan vaskular yang mendasari disfungsi vaskular pada hipertensi dan penyakit kardiovaskular. Konsekuensi klinisnya meliputi disfungsi mikrovaskular di otak, jantung, dan jaringan sistemik, serta percepatan perkembangan terjadinya aterosklerosis $[3,4]$. Model tikus yang diinduksi Deoxycorticosterone acetate-salt
(DOCA-salt) adalah model hipertensi endokrin yang berkembang dengan cepat menjadi hipertensi berat dan stres oksidatif [5], memungkinkan pemahaman tentang perkembangan penyakit dan pengujian terapi potensial dimana potensi penggunaan ekstrak etanol ubi jalar ungu, yang mengandung asam klorogenat sebagai agen terapeutik.

Ubi jalar ungu diketahui memiliki beberapa keunggulan dibandingkan ubi jalar lainnya dalam hal potensi penurunan hipertensi. Ubi jalar mengandung antosianin, protein dioscorin, dan asam klorogenat yang berfungsi sebagai agen antihipertensi [6]. Asam klorogenat memiliki kemampuan untuk menurunkan tekanan darah dengan cara menghambat aktivitas beberapa enzim kunci, seperti Angiotensin-converting enzyme (ACE), yang terlibat dalam patogenesis hipertensi, dan mampu mencegah kerusakan oksidatif di tingkat seluler. ACE memiliki peran penting dalam mengubah angiotensin-I menjadi angiotensin-II dengan memblokir situs aktif enzim $[7,8]$. Angiotensin-II merupakan vasokonstriktor kuat dan stimulator untuk sintesis dan pelepasan aldosteron, yang kemudian meningkatkan tekanan darah dengan mempromosikan retensi natrium di tubulus distal $[2,7,8]$.

Berdasarkan pertimbangan di atas, penghambatan ACE dapat berguna dalam 
pengobatan hipertensi $[2,9]$. Oleh karena itu, pemberian antioksidan dianggap sebagai pendekatan terapeutik yang berguna dalam pengobatan tekanan darah tinggi. Untuk memahami efek ketergantungan dosis ekstrak etanol perlakuan asam klorogenat turunan ubi jalar ungu pada tekanan darah sistolik (SBP) dan konsentrasi aktivitas renin, ACE, dan Ang II, kami menggunakan tikus putih (Rattus norvegicus) strain Wistar yang diinduksi oleh DOCA-salt sebagai model hewan hipertensi.

\section{METODE PENELITIAN \\ Rancangan/Desain Penelitian}

Jenis penelitian yang digunakan adalah quasi experimental. Rancangan penelitian adalah Rancangan Acak Lengkap (RAL) dengan 5 perlakuan yaitu tikus normal (kontrol negatif), tikus hipertensi (kontrol positif), pemberian EU $200 \quad \mathrm{mg} / \mathrm{kgBB} \quad(\mathrm{P} 1), \quad$ EU 400 $\mathrm{mg} / \mathrm{kgBB}$ (P2), dan AK 0,4 mg/kg BB (P3) yang menggunakan tikus sebagai subjek penelitian. Penelitian ini telah dinyatakan laik etik oleh Komisi Etik Universitas Brawijaya dengan No. 724KEP-UB.

\section{Sumber Data}

Pemeliharaan tikus ini dilakukan di laboratorium biomedik Fakultas Kedokteran Hewan Universitas Brawijaya dan pengujian aktivitas ACE, aktivitas renin, dan kadar Angiotensin II tikus dilakukan di Laboratorium Biosains, Universitas Brawijaya. Ubi jalar ungu var. Ayamurasaki didapatkan dari BALITKABI Malang. Untuk tikus model hipertensi

Deoxycorticosterone menggunakan (DOCA-salt) (Sigma, Pcode 1001376001). Asam klorogenat digunakan sebagai perlakuan karena merupakan senyawa bioaktif pada ubi jalar ungu. Proses ekstraksi etanol dilakukan dengan tepung ubi ungu diekstraksi dengan pelarut etanol 95\% dalam suasana asam, diberi larutan $\mathrm{HCl}$ sehingga memiliki $\mathrm{pH}$ antara 1-3, dengan nisbah sampel kering tepung ubi jalar ungu dan pelarut etanol $=1: 7$. Ekstraksi dilakukan secara maserasi selama 3 hari kemudian dilakukan remaserasi selama 2 hari sambil sesekali diaduk. Pengadukan bertujuan untuk meratakan konsentrasi larutan di luar serbuk simplisia agar tidak terjadi kejenuhan sehingga proses osmosis dan difusi terus berjalan. Ekstrak etanol yang didapat dikumpulkan lalu ekstrak dikentalkan menggunakan waterbath hingga didapatkan ekstrak etanol ubi jalar ungu (EU).

\section{Sampel Penelitian}

Semua prosedur dilakukan sesuai dengan pedoman konvensional untuk eksperimen pada hewan coba. Penelitian ini menggunakan tikus putih (Rattus norvegicus) strain Wistar jantan berumur dua belas minggu sebanyak 30 ekor. Tikus-tikus tersebut dibagi menjadi lima kelompok, yaitu normotensif (NTN) (A); hipertensi (HTN) (B), HTN + ekstrak etanol (EP) pada setengah dosis standar (200 mg/kg BB (C); dosis standar HTN + EP $400 \mathrm{mg} / \mathrm{kgBB}$ (D), dan HTN + Asam klorogenat (AK) 0,4 mg/kgBB (E). Tikus ditempatkan lima ekor per kandang, diberi kode nomor untuk replikasi, dalam lingkungan yang diatur dengan siklus terang/gelap 12 jam. Tikus hipertensi disiapkan dengan induksi DOCA-salt, dua kali seminggu selama lima minggu (10 suntikan). Untuk pemberian, DOCAsalt dilarutkan dalam $0,5 \mathrm{ml}$ minyak jagung [10]. DOCA disuntikkan secara subkutan di tulang belakang leher dengan lima dosis pertama $20 \mathrm{mg} / \mathrm{kg}$, dan lima dosis terakhir $10 \mathrm{mg} / \mathrm{kg}$. Tikus diberi $\mathrm{NaCl} 1 \%$ sebagai air minum. Tikus dalam kelompok $\mathrm{C}$ dan $\mathrm{D}$ dilakukan pemberian oral, menggunakan kanul, dengan dosis harian EU pada 200 dan $400 \mathrm{mg} / \mathrm{kg} \mathrm{BB}$ serta kelompok $\mathrm{E}$ dengan dosis harian AK $0,4 \mathrm{mg} / \mathrm{kg} \quad \mathrm{BB}$, masing-masing, dilarutkan dalam air osmosis, selama 4 
minggu berturut-turut. Kelompok kontrol menerima diet normal.

\section{Pengembangan Instrumen dan Teknik Pengumpulan Data}

Penentuan kadar asam klorogenat dari EU dimana pada sampel ekstrak EU, diambil $200 \mu \mathrm{L}$ fasa organik (bagian atas) dan dimasukkan ke dalam vial LC. Kemudian dikeringkan dalam suhu ruang. Larutkan kembali residu dengan aquabides lalu diaduk selama 5 menit agar residu terlarut sempurna. Setelah itu sampel diinjeksikan dalam sistem LC dan diukur luas peak dari asam klorogenat lalu perhitungan menggunakan persamaan garis dari kurva linearitas untuk menentukan kadar dari asam klorogenat yang terkandung dalam sampel EU.

Parameter yang diukur adalah aktivitas ACE, aktivitas renin, dan kadar angiotensin II dilakukan dengan menggunakan ELISA kit. Standar, blanko, dan sampel dimasukkan ke dalam well 50 L (kecuali well blank), dihomogenkan, diinkubasi selama 30 menit pada suhu $37^{\circ} \mathrm{C}$ dan dicuci dengan $200 \mathrm{~L}$ wash buffer yang ditambahkan pada setiap well (diulang 5 kali, sampai semua cairan hilang). Kemudian ditambahkan HRPConjugate sebanyak $50 \mathrm{~L}$ pada setiap well (kecuali well blank) dan dilanjutkan dengan homogenisasi. Plat ditutup rapat dan diinkubasi selama 30 menit pada suhu $37^{\circ} \mathrm{C}$. Pencucian dilakukan dengan wash buffer 200 L pada setiap well (diulang 5 kali, sampai semua cairan hilang). Setiap well kemudian ditambahkan dengan 50 L larutan kromogen A dan 50 L larutan kromogen B. Pelat ditutup rapat dan diinkubasi selama 10 menit pada suhu $37^{\circ} \mathrm{C}$, selama inkubasi dihindarkan dari cahaya. Selanjutnya ditambahkan 50 L stop solution pada masing-masing well (apabila 4 well yang mengandung konsentrasi standar tertinggi berubah warna menjadi biru, jika perubahan warna tidak seragam, dilakukan homogenisasi dengan shaker). Pengukuran kinerja absorbansi pada 450 nm pada rentang waktu 15 menit secara cepat dilakukan dengan menggunakan ELISA reader [10].

\section{Teknik Analisis Data}

Hasil pengukuran aktivitas renin, aktivitas ACE, dan kadar Ang II dinyatakan sebagai mean \pm standar deviasi (SD). Perbedaan antarkelompok uji dianalisis secara statistik menggunakan analisis varians (ANOVA), dilanjutkan dengan uji Post Hoc Tukey untuk menentukan perbedaan signifikan pada $\mathrm{p}<0,05$. Seluruh analisis statistik dilakukan menggunakan program SPSS versi 16.

\section{HASIL PENELITIAN}

Penelitian ini dilakukan untuk mengetahui pengaruh ekstrak etanol ubi jalar ungu dan asam klorogenat untuk menurunkan tekanan darah sebagai fungsi ACE inhibitor. Untuk menentukan sistem renin angiotensin aldosterone system (RAAS) masih berpengaruh pada pengaturan tekanan darah untuk model hipertensi yang diinduksi DOCA-salt, maka diuji aktivitas ACE dan renin dan konsentrasi angiotensin II (Ang-II) terhadap kelompok tikus normotensif (NTN), kelompok tikus penderita hipertensi (HTN), dan kelompok tikus HTN yang diberi ekstrak etanol ubi jalar ungu (EU) dan asam klorogenat (AK).

Ekstrak etanol ubi jalar ungu diidentifikasi menggunakan LC/MS. Seperti tampak pada Gambar 1, rerata kandungan asam klorogenat dalam sampel adalah 3,340 $\mu \mathrm{g}$ dalam $1 \mathrm{~g}$ ekstrak etanol ubi jalar ungu. 


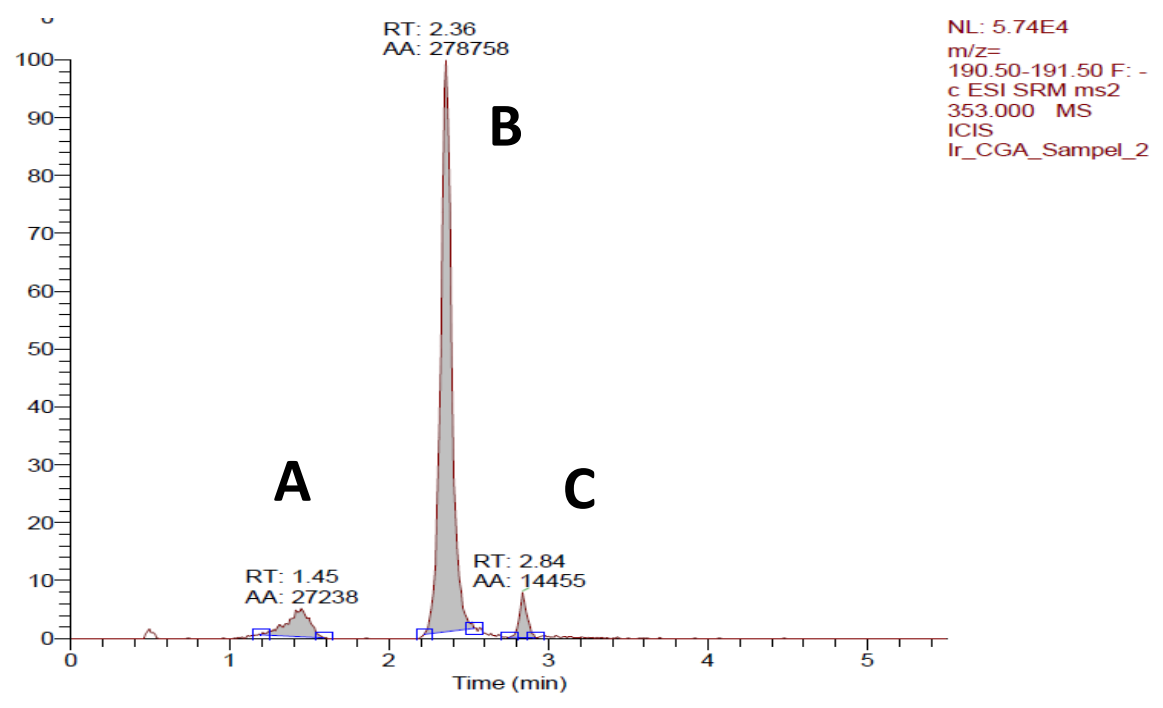

\section{Gambar 1. Kromatogram Sampel Ekstrak Ubi Jalar Ungu (EU)}

Keterangan: Peak pada RT 2,36 dalam kromatogram adalah asam klorogenat, $A=$ Asam Kafeat; $B=A s a m$ klorogenat; $\mathrm{C}=$ As. 3,5-di-O-kafeoilkuinat

Tabel 1. Pengaruh Ekstrak Etanol Ubi Jalar Ungu (EU) dan Asam Klorogenat (AK) terhadap Aktivitas Renin dan Aktivitas ACE

\begin{tabular}{lcc}
\hline Kelompok Perlakuan & Renin (U/L) & ACE (U/L) \\
\hline K- (Normal-NTN) & $303,6 \pm 5,54^{\mathrm{a}}$ & $15,03 \pm 0,74^{\mathrm{a}}$ \\
K+ (Hipertensi-HTN) & $554,8 \pm 7,11^{\mathrm{c}}$ & $19,37 \pm 0,90^{\mathrm{c}}$ \\
P1 (HTN +EU 200) & $404,8 \pm 8,40^{\mathrm{b}}$ & $18,24 \pm 0,35^{\mathrm{b}}$ \\
P2 (HTN +EU 400) & $312,2 \pm 5,94^{\mathrm{a}}$ & $15,95 \pm 0,40^{\mathrm{a}}$ \\
P3 (HTN +AK ) & $314,0 \pm 6,61^{\mathrm{a}}$ & $15,89 \pm 0,20^{\mathrm{a}}$ \\
\hline
\end{tabular}

*Keterangan: data merupakan rerata dari 5 kali ulangan

${ }^{\mathrm{abc}}$ Huruf yang berbeda pada kolom yang sama menunjukkan perbedaan bermakna $(\mathrm{p}<0,05)$

Tabel 1 menunjukkan bahwa pada kelompok tikus hipertensi, aktivitas enzim renin $(554,8 \pm 7,11 \mathrm{U} / \mathrm{L})$ dan enzim $\mathrm{ACE}$ $(19,37 \pm 0,90 \quad$ U/L $)$ lebih tinggi secara signifikan, dan terjadi penurunan yang berbeda nyata $(\mathrm{p}<0,05)$ setelah diberi perlakuan ekstrak etanol ubi jalar ungu. Data aktivitas enzim renin, kelompok P2 (312,2 $\pm 5,94$ U/L) dan P3 (314,0 06,61 $\mathrm{U} / \mathrm{L})$ mampu menurunkan aktivitas enzim ACE lebih baik $(\mathrm{p}<0,05)$ dibandingkan P1 $(404,8 \pm 8,40 \quad \mathrm{U} / \mathrm{L})$ terhadap kontrol positif. Hasil yang sama juga ditemukan pada aktivitas enzim ACE, kelompok perlakuan P2 $(15,95 \pm 0,40$ U/L $)$ dan P3 $(15,89 \pm 0,20$ U/L) menurunkan aktivitas enzim ACE lebih besar berbeda nyata $(\mathrm{p}<0,05)$ dibandingkan P1 $(18,24 \pm 0,35 \quad \mathrm{U} / \mathrm{L})$ terhadap kontrol positif. 
Tabel 2. Pengaruh Ekstrak Etanol Ubi Jalar Ungu (EU) dan Asam Klorogenat (AK) terhadap Kadar Angiotensin II

\begin{tabular}{lc}
\hline Kelompok Perlakuan & Ang II (pg/mL) \\
\hline K- (Normal-NTN) & $788,94 \pm 9,52^{\mathrm{a}}$ \\
K+ (Hipertensi-HTN) & $928,35 \pm 11,36^{\mathrm{c}}$ \\
P1 (HTN +EU 200) & $851,88 \pm 7,12^{\mathrm{b}}$ \\
P2 (HTN +EU 400) & $805,29 \pm 11,75^{\mathrm{a}}$ \\
P3 (HTN +AK) & $794,82 \pm 18,01^{\mathrm{a}}$ \\
\hline
\end{tabular}

*Keterangan: data merupakan rerata dari 5 kali ulangan

${ }^{\mathrm{abc}}$ Huruf yang berbeda pada kolom yang sama menunjukkan perbedaan bermakna $(\mathrm{p}<0,05)$

Hasil yang sama juga ditemukan pada kadar Ang II (Tabel 2). Kadar Ang II pada kontrol positif memiliki nilai paling tinggi secara signifikan dibandingkan dengan kelompok perlakuan lain $(928,35 \pm 11,36 \mathrm{U} / \mathrm{L})$ dan pemberian ekstrak etanol ubi jalar ungu dan asam klorogenat mampu menurunkan kadar Ang II secara bermakna, yaitu P2 $(805,29 \pm 11,75$ U/L) dan P3 (794,82 $\pm 18,01 \mathrm{U} / \mathrm{L})$.

Pemberian ekstrak etanol ubi jalar ungu (EU) yang mengandung asam klorogenat dapat menurunkan aktivitas enzim renin, aktivitas enzim ACE, dan konsentrasi Ang II (Tabel 1 dan 2). Pemberian terapi EU dosis 200 dan $400 \mathrm{mg} / \mathrm{kg}$ BB (P1 dan P2) serta asam klorogenat (P3) memberikan hasil penurunan yang berbeda nyata $(\mathrm{p}<0,05)$ terhadap kontrol positif (hipertensi). Hasil ini menyatakan bahwa perlakuan P1 sudah dapat menurunkan aktivitas enzim renin, ACE dan kadar Ang II berbeda nyata $(p<0,05)$ dibandingkan dengan kontrol negatif (normal) tetapi masih belum dapat mencapai kondisi normal (tidak berbeda nyata $(\mathrm{p}<0,05)$ dengan kontrol negatif), sedangkan perlakuan P2 dan P3 sudah mendekati kondisi normal (tidak berbeda nyata $(\mathrm{p}<0,05)$ dengan kontrol negatif).

\section{PEMBAHASAN}

Hipertensi induksi DOCA-salt merupakan model hipertensi endokrin dimana fungsi RAAS terhambat, dan menyebabkan kadar plasma dari enzim renin maupun Ang II menurun [5,11], sehingga dilakukan evaluasi peran ACEinhibitor (ACE-I) dari ekstrak etanol ubi jalar dan asam klorogenat terhadap perubahan aktivitas enzim renin dan aktivitas enzim ACE. DOCA-salt memengaruhi mekanisme kerja RAAS (renin angiotensin aldosteron system) diawali dengan sekresi renin oleh sel jukstaglomerulus (JG) yaitu enzim yang mengkatalisis proses hidrolisis Angiotensin (Ang) I dari N-terminus angiotensinogen. Selanjutnya Ang I akan dihidrolisis oleh ACE menghasilkan Ang II yang merupakan produk utama dari sistem RAAS dan berfungsi sebagai potensial vasokonstriktor yang sangat berperan pada kasus hipertensi [11].

Enzim ACE adalah zinc metallopeptidase (dipeptidylkarboksipeptidase) yang diekspresikan pada permukaan banyak sel dan mempunyai fungsi mengatalisis konversi Ang I menjadi Ang II yang merupakan potensial vasokonstriktor serta degradasi bradykinin yang merupakan vasodilator. Enzim ACE mempunyai peranan penting dalam regulasi tekanan darah sehingga inhibisi kerja enzim ACE dapat memberikan efek hipotensi. Selain sebagai ACE-I, efek antihipertensi dapat terjadi melalui beberapa mekanisme lain yaitu inhibisi pelepasan endhotelin-1 oleh sel endhotelial, stimulasi aktivitas bradykinin, meningkatkan produksi nitrit oksida oleh endhotelium, dan meningkatkan reaksi vasodilator dengan 
reseptor opiate. Peningkatan aktivitas fenolik sebagai inhibitor ACE dapat ditingkatkan melalui hidrolisis secara enzimatik [12].

Penelitian Bare et al. tahun 2019 juga menunjukkan efek positif senyawa asam klorogenat dalam menghambat aktivitas enzim ACE secara metode in silico. Asam klorogenat sebagai ACE-I ini memiliki peran penting dalam menghambat regulasi sistem reninangiotensin yang dibuktikan dengan adanya ikatan asam klorogenat dengan 16 residu asam amino, sehingga tidak terjadi konversi Ang I menjadi Ang II [13].

Asam klorogenat memiliki potensi aktivitas sebagai antihipertensi karena metabolit dari asam klorogenat mengurangi terjadinya stres oksidatif yang berefek pada penurunan tekanan darah melalui peningkatan fungsi endotel dan peningkatan bioavailabilitas nitrit oksida (NO) di pembuluh darah arteri serta penghambatan ACE. Asam klorogenat dalam peranannya menurunkan darah, yaitu menghambat aktivitas enzim ACE sehingga kadar Ang II yang terbentuk menurun dan menyebabkan efek vasodilatasi (merelaksasikan pembuluh darah dan menurunkan tekanan darah) [14].

Ang II selain sebagai vasokonstriktor kuat, juga berkontribusi untuk merangsang produksi superoksida dalam jumlah banyak. Penurunan produksi radikal bebas menyebabkan penurunan tingkat stres oksidatif, sehingga antioksidan endogen dapat memberikan terapi efek pada tubuh [15].

Pada kondisi hipertensi terjadi peningkatan aktivitas renin, ACE, dan kadar Ang II yang cukup tinggi dan menurun setelah diberi terapi ekstrak etanol ubi jalar ungu. Hasil penelitian ini menjelaskan bahwa sistem renin angiotensin masih berperan pada regulasi tekanan darah hewan tikus model DOCA-salt dengan pemberian ekstrak etanol ubi jalar ungu dan asam klorogenat yang mengandung senyawa bioaktif dengan aktivitas ACE-I yang cukup tinggi sehingga mampu menghambat perubahan Ang I menjadi Ang II.

Aktivitas enzim renin dan enzim ACE berpengaruh positif dan signifikan terhadap kadar Ang II. Hal ini berarti setiap peningkatan aktivitas enzim renin dan enzim ACE dapat menaikkan kadar Ang II. Kadar Ang II berpengaruh positif dan signifikan terhadap tekanan darah. Setiap peningkatan Ang II dapat menaikkan tekanan darah. Ang II sebagai vasokonstriktor yang menyebabkan pelebaran pembuluh darah sehingga menyebabkan peningkatan tekanan darah (hipertensi) [16].

Pengujian secara in vitro telah dilakukan dan menunjukkan asam klorogenat mempunyai kumpulan cixinal hydroxyl pada residu aromatis yang berfungsi sebagai antioksidan. Aktivitas antioksidan yang bekerja pada ROS (Reactive Oxygen Species). ROS dapat menyebabkan iskemia dan kerusakan usus, sedangkan antioksidan dapat menghapus ROS. Asam klorogenat memiliki $\mathrm{IC}_{50}$ sebesar 5,86 ppm dengan metode DPPH. Nilai $\mathrm{IC}_{50}$ merupakan parameter yang dipakai untuk menunjukkan aktivitas antioksidan yang memberikan penghambatan $50 \%$. Zat yang mempunyai aktivitas antioksidan tinggi memiliki nilai $\mathrm{IC}_{50}$ yang rendah. Asam klorogenat mempunyai banyak gugus hidroksil yang berpengaruh terhadap aktivitas antioksidan $[17,18]$.

Asupan asam klorogenat dapat meningkatkan bioavailabilitas NO pada pasien hipertensi karena asam ferulic, metabolit 5-CQA, membuang superoksida. Hipertensi disebabkan oleh adanya peningkatan kadar $\mathrm{H}_{2} \mathrm{O}_{2}$ dan anion superoksida. Anion superoksida mengurangi bioavailabilitas NO dalam jaringan endotel dengan cara bereaksi dengan NO menghasilkan peroxynitrit 
(ONOO-), sehingga NO akan berkurang. NO berfungsi untuk melemaskan pembuluh darah sehingga dapat menurunkan tekanan darah, ketika NO berkurang maka dapat menyebabkan hipertensi $[19,20]$.

\section{SIMPULAN}

Potensi sifat antihipertensi asam klorogenat dan ekstrak etanol ubi jalar ungu dalam penelitian ini menunjukkan efek yang signifikan dalam menghambat aktivitas konsentrasi renin, ACE, Ang II pada model tikus hipertensi DOCA-salt. Temuan ini menunjukkan bahwa asam klorogenat dari ekstrak etanol ubi jalar ungu dapat dianggap sebagai agen antihipertensi potensial yang tahan terhadap protease pencernaan. Namun, penelitian lebih lanjut diperlukan untuk mengevaluasi bioavailabilitas dari asam klorogenat yang berasal dari ubi jalar setelah pencernaan, yang dapat menjadi faktor signifikan yang memengaruhi efektivitas komponen pangan nutraceutical.

\section{DAFTAR RUJUKAN}

1. Rubattu S, Pagliaro B, Pierelli G, Santolamazza C, Di Castro S, Mennuni S, Volpe M. Pathogenesis of Target Organ Damage in Hypertension: Role of Mitochondrial Oxidative Stress. Int. J. Mol. Sci. 2015; 16 (1): 82339.

2. Moon JY. Recent Update of Reninangiotensin-aldosterone System in The Pathogenesis of Hypertension. Electrolyte Blood Press. 2013; 11 (2): 41-5.

3. Masi S, Uliana M, Virdis A. Angiotensin II and Vascular Damage in Hypertension: Role of Oxidative Stress and Sympathetic Activation. Vascul Pharmacol. 2019; 115: 13-7.

4. Guzik TJ, Touyz RM. Oxidative Stress, Inflammation, and Vascular
Aging in Hypertension. Hypertension. 2017; 70 (4): 660-7.

5. Dornas WC, Silva ME. Animal Models for The Study of Arterial Hypertension. J Biosci. 2011; 36 (4): 731-7

6. Tanaka $\mathrm{M}$, Ishiguro $\mathrm{K}$, Oki $\mathrm{T}$, Okuno S. Functional Components in Sweetpotato and Their Genetic Improvement. Breed Sci. 2017; 67 (1): 52-61.

7. Agunloye OM, Oboh G, Ademiluyi AO, Ademosun AO, Akindahunsi AA, Oyagbemi AA, et al. Cardioprotective and Antioxidant Properties of Caffeic Acid and Chlorogenic Acid: Mechanistic Role of Angiotensin Converting Enzyme, Cholinesterase and Arginase Activities in Cyclosporine Induced Hypertensive Rats. Biomed Pharmacother. 2019; 109: 450-8.

8. Onakpoya IJ, Spencer EA, Thompson MJ, Heneghan CJ. The Effect of Chlorogenic Acid on Blood Pressure: A Systematic Review and Meta-Analysis of Randomized Clinical Trials. J. Hum. Hypertens. 2015; 29 (2): 77-81.

9. Flaten HK, Monte AA. The Pharmacogenomic and Metabolomic Predictors of ACE Inhibitor and Angiotensin II Receptor Blocker Effectiveness and Safety. Cardiovasc Drugs Ther. 2017; 31 (4): 471-82.

10. Khorshid O, Abdel-Ghaffar E, Mishriki A, Galal A, Hareedy A. Possible Cardiovascular Protective Effect of Some PPAR Activators in Experimentally-Induced Hypertensive Model in Rats. Asian $\mathrm{J}$ of Pharmaceutic and Clin Res. 2012; 5 (3):67-72.

11. Basting T, Lazartigues E. DOCASalt Hypertension: An Update. Curr Hypertens Rep. 2017; 19 (4): 32.

12. Ji H, Zhang HX, Li HT, Li YC. Analysis on The Nutrition 
Composition and Antioxidant Activity of Different Types of Sweet Potato Cultivars. Food and Nutrition Sciences. 2015; 6 : 161-167.

13. Bare Y, Sari DR, Rachmad YT, Tiring SSND, Rophi AH, Nugraha FAD. Prediction Potential Chlorogenic Acid as Inhibitor ACE (in Silico Study). Bioscience. 2019; 3 (2): 197-203.

14. Zhao Y, Wang J, Ballevre O, Luo H, Zhang W. Antihypertensive Effects and Mechanisms of Chlorogenic Acids. Hypertens Res. 2012; 35 (4): 370-4.

15. Jawi IM, Sutirta-Yasa IWP, Mahendra AN. Antihypertensive and Antioxidant Potential of Purple Sweet Potato Tuber Dry Extract in Hypertensive Rats. Bali Med J. 2016; 5 (2): 252-255.

16. Sridevi P, Prashanth KS, Bhagavan MR. Angiotensin Converting Enzyme: A Target for AntiHypertensive Drugs. Int J Res Pharm Biomed Sc. 2011; 2: 63-72.
17. Park JS, Woo JW, Choi GH, Choi DS, Jung MY. Chlorogenic Acid Profiles and Antioxidant Potentials of 17 Sweet Potato Varieties Cultivated in Korea: Impact of Extraction Condition and Classification by Hierarchical Clustering Analysis. J Food Chem Nanotechnol. 2015; 1 (1): 3-12.

18. Naveed M, Hejazi V, Abbas M, Kamboh AA, Khan GJ, Shumzaid $\mathrm{M}$, et al. Chlorogenic acid (CGA): A Pharmacological Review and Call for Further Research. Biomed Pharmacother. 2018; 97: 67-74.

19. González J, Valls N, Brito R, Rodrigo R. Essential Hypertension and Oxidative Stress: New Insights. World J Cardiol. 2014; 6 (6): 353366.

20. Pinheiro LC, Tanus-Santos JE, Castro MM. The Potential of Stimulating Nitric Oxide Formation in The Treatment of Hypertension. Expert Opin Ther Targets. 2017; 21 (5): 543-56. 